\title{
THE RIGHTS OF THE STATES AND ADJACENT OWNERS OF PROPERTY IN THE MAINTE- NANCE AND OPERATION OF A RAILROAD
}

\author{
Chardes Willis NeEdham
}

The statistical number of the Railway Age (January 4, I9I8, page 49) gives an account of the abandonment of I 300 miles of railroad in I9I7. The miles abandoned exceeded the miles of new construction that year. After referring to the new mileage for previous years the article states:

"In I9I7, however, there was 45 I miles of railroad actually taken up. or in the process of being taken up and sold for junk. In addition there was 49I miles of road on which operation was abandoned, and 396 miles of road which the owners had asked permission from State commissions or legislatures to abandon; and, as a matter of fact, this latter figure does not represent all of the road, which would be taken up and sold as junk if the owners could get permission so to do."

Since I9I7, 4,262.26 miles of railroad have been abandoned, with or without permission from state or federal authorities and petitions by several companies for leave to abandon the whole or parts of their respective lines are now pending before state and federal commissions involving several hundred miles of railroad. There is also under discussion, by parties in interest, the proposed abandonment of other lines where the operating expenses greatly exceed the gross revenues of the roads. Considering the public and private interests involved, the subject is of vital interest and calls for thoughtful legislative consideration by the states and the federal government.

Two questions are presented: (I) Has a railroad company the right to take up and remove its permanent tracks, bridges, turnouts, switches, and fixtures attached to the right of way, and discontinue all operation as a common carrier on such line, without the consent of (a) the state in which it operates and the federal government in cases where the line is used in interstate commerce, and (b) the adjacent land owners who are directly and financially affected by the abandonment of the line? (2) Upon what terms and conditions should such consent be given?

Before discussing these questions it is well to have a clear conception of the legal character and status of a common carrier railroad as determined by judicial authority in this country.

\section{I}

A public railroad is a "highway" differing only from the ordinary highway in the ownership and the manner or mode of its use. Mr.

[See, on this same general subject, CoMMENTS (I922) 32 YALE LAw JourNaL, 75. Ed.] 
Justice Strong, speaking for the Supreme Court of the United States, said : ${ }^{1}$

"That railroads, though constructed by private corporations and owned by them, are public highways, has been the doctrine of nearly all the courts ever since such conveniences for passage and transportation have had any existence. . . . . It has never been considered a matter of any importance that the road was built by the agency of a private corporation. No matter who is the agent the function performed is that of the state. Though the ownership is private, the use is public. .... That all persons may not put their own cars upon the road, and use their own motive power, has no bearing upon the question whether the road is a public highway. It bears only upon the mode of use, of which the legislature is the exclusive judge."

The construction of railroads, like the opening of ordinary streets and highways, requires the exercise of sovereign powers and legislative discretion. It is to meet and supply a public need. It is necessary to the enlargement and efficiency of government. Population, wealth. public revenues, are all dependent upon the extension of highways. The increase of population in sparsely settled or unoccupied territory, the growth of private and national wealth by the development of natural resources, and the fabrication of manufactured products all depend upon transportation. People will go just as far into the wilderness and settle as they can go and produce something which they can market at a little more than the cost of production. The marketing depends upon transportation. The ordinary highway will carry a people back into the interior a short distance; turnpikes will induce them to go further; canals will connect waterways and extend a population over a very large territory; and a highway with rails, operated by steam or electricity, will cover a continent with a population and thriving industries. A state can no more do without these public facilities, of high efficiency, than it can do without court houses, custom houses, jails, and public buildings. They are an essential and integral part of every civilized government; and, as we know today, better than ever before, that nation is strongest and most efficient in peace and in war that has the best and most improved system of transportation. To build public highways of every kind is a "function of the State."2

The state may furnish highway facilities of any type in either of two ways: It may build them or it may permit persons or corporations to build them. In either case they are public highways, an inducement to people to go out along them, settle, build homes and industrial plants, and the use and continuance of such highways are subject to governmental regulation and control.

${ }^{1}$ Olcott v. Supervisors (1872, U. S.) I6 Wall. 678, 694 et seq.

${ }^{2}$ Lake Shore and Mich. So. Ry. v. Ohio (1899) I73 U. S. 285, 302, I9 Sup. Ct. 465, 472; United States v. Joint Traffic Assn. (1898) I7I U. S. 505, 569 et seq., .I9 Sup. Ct. 25, 32. 
II

Early in our history it became the public policy of our government, as in England and some other countries, to construct and operate highways requiring large expenditures of capital, such as toll roads, canals, and railroads, through the agency of corporations with private capital, organized under legislative acts. This policy resulted in creating three distinct interests in the highways so constructed: (a) the private capital interest, represented in the rights of the companies, (b) the public interest, the general welfare of the state, and (c) the material interests of local people who, accepting this governmental provision, have gone out along the railroad into new territory and invested their money in homes and.business enterprises depending upon the highway thus established, and its maintenance, for access to market cities. The first property interest is specially protected by the Constitution of the United States, hereinafter commented upon, and the public interest is paramount in all matters of constitutional regulation. There is a contract obligation on the part of each company to operate its highway to and for the convenience of the public so long as it retains its charter or charter rights. A few cases may be here noted in support of the propositions stated.

Mr. Justice Bradley (dissenting on other points, Justices Gray and Lamar concurring) said: $:^{3}$

"When a railroad company is chartered it is for the purpose of performing a duty which belongs to the State itself. It is chartered as an agent of the State for furnishing public accommodations. The State might build its railroads if it saw fit."

Mr. Justice Peckham, speaking upon this subject for the court, said :5

"When the matter of the building of railroads as highways arose, a question was presented whether the State should itself build them or permit others to do it. The State did not build them, and as their building required, among other things, the appropriation of land, private individuals could not enforce such appropriation without a grant from the State."

Mr. Justice Peckham, again speaking for the court, said : ${ }^{6}$

"A State may furnish such facilities or direct them to be furnished by persons or corporations within its limits without violating the Federal Constitution. .... Railroads have from the very outset been regarded as public highways and the right and the duty of the government to regulate in a reasonable and proper manner the conduct and business of railroad corporations have been founded upon that fact.

${ }^{2}$ Chicago, etc., Ry. v. Mimesota (I89o) I34 U. S. 4I8, 46I, Io Sup. Ct. 702, at p. 703.

'Minnesota Rate Cases (1913) 230 U. S. 352, 416, 33 Sup. Ct. 731, 747.

"United States v. Joint Traffic Assn. (I898) I7I U. S. 505, 569, I9 Sup. Ct. 25, 32.

'Wisconsin, etc., Ry. v. Jacobson (1900) I79 U. S. 287, 295 et seq., 2I Sup. Ct. II5, II8 et seq. 
Constituting public highways of a most important character, the function of proper regulation by the government springs from the fact that in relation to all highways the duty of regulation is governmental in its nature. At the present day there is no denial of these propositions. .... It is because they are such highways that the land upon which the rails are laid, and also that which may be necessary for the other - purposes of the corporation, is said to be used for a public purpose, and on that ground the power of eminent domain which is given them is held to be a constifutional exercise of legislative authority. .... They are organized for the public interests and to subserve primarily the public good and convenience."

Mr. Justice Harlan, speaking for the court, said :?

"The question is no longer an open one, as to whether a, railroad is a public highway, established primarily for the convenience of the people. and to subserve public ends, and subject to governmental control and regulation. It is because it is a public highway, . . . that the corporation by which it is constructed, and .... maintained may be permitted under legislative sanction, to appropriate private property. ...."

Mr. Justice Holmes, speaking for the court, said :

"The general principles to be applied are not open to controversy. The railroad property is private property devoted to a public use. As a corporation, the owner is subject to the obligations of its charter."

On the private side the capital and property of the quasi-public corporation are protected by the provisions of the federal constitution." Mr. Justice Holmes, speaking for the court, said :10

"A carrier cannot be compelled to carry on even a branch of business at a loss, much less the whole business of carriage. .... It is true that if a railroad continues to exercise the powers conferred upon it by a charter from a State, the State may require it to fulfil an obligation imposed by the charter even though fulfilment in that particular may cause a loss."

And in another case the same Justice, speaking for the court, said:11 "If the burdens imposed are so great that the road cannot be run at a profit, it can stop, whatever the misfortunes the stopping may produce." $" 12$

"Cherokee Nation v. Kansas Ry. (1890) I35 U. S. 64I; 657, 1o Sup. Ct. 965, 971.

${ }^{8}$ Northern Pacific Ry. v. North Dakota (I9I5) 236 U. S. 585, 595, 35 Sup. Ct. 429,432 et seq.

${ }^{9}$ United States Const. (1789) Amendments 5 and I4.

${ }^{10}$ Brooks-Scanlon Co. v. Ry. Comm. (rgIg) 25I U. S. 396, 399, 40 Sup. Ct. I83, 184.

${ }^{11}$ Erie Ry. v. Public Utilties Comm. (I92I) 254 U. S. 394, 4II, 4I Sup. Ct. I69, I7x.

${ }^{12}$ See also statement by Mr. Justice Hughes, speaking for the court, in Northern Pacific Ry. v. North Dakota (IgI5) 236 U. S. at p. 595, 35 Sup. Ct. at p. 433 ; and Norfolk and Western Ry. v. West Virginia (I9I5) 236 U. S. 605, 608 et seq., 35 Sup. Ct. 437 et seq. 
That a railroad company may be compelled, so long as it retains its charter rights, to operate its line and extend its facilities for serving the public, even at a loss, is clearly established..$^{13}$

Thus has the character and the status of a common carrier railroad been clearly stated by the highest judicial authority of the land. Aside from the protection given to the private capital invested in these highways the reasons for continuing the maintenance and operation of a railroad are the same that exist in reference to the continuance of any highway.

III

Coming now to our first question: Has a railroad company the right to take up and remove its tracks, etc., and discontinue operation without the consent (A) of the state in which it operates and of the federal gov- ernment in cases where the line is used in interstate commerce; and (B) the consent of adjacent land owners financially affected by such abandonment?

The word "state" will be used in this paper in its generic sense and not with reference to states in the federal union, unless otherwise indicated.

Investing private capital in a public service corporation is voluntary on the part of the investor. He invests for the purpose and with the expectation of gain, but, like an investor in a purely private enterprise, he assumes the risk of its being unprofitable. While it is a government function to build rail highways and the government by its public policy invites private capital to perform this function, there is no guarantee by the government that there will be no loss of the capital so invested. ${ }^{14}$ If the venture proves profitable, the profits go to the investor; if it proves unprofitable and a loss occurs, the loss must be borne by the private capital so invested. If serious loss has been sustained in an endeavor to build a railroad and it appears that further losses will be incurred by continuing the operation, the private investor has the right to abandon the operation and withdraw that part of his capital which remains, subject, however, to such regulations by the state as will secure justice to all financially affected by such withdrawal. The right of a carrier to abandon a highway that can be operated only at a loss, steadily diminishing the capital invested, is acknowledged, but only with the

\footnotetext{
${ }^{13}$ Northern Pacific Ry. v. Dustin (1892) I42 U. S. 492, I2 Sup. Ct. 283; Missouri Pacific Ry. v. Kansas (1910) 216 U. S. 262, 270, 278 et seq., 30 Sup Ct. 330, 332, 336; Detroit, etc., Ry. v. Michigan Ry. Comm. (rgr6) 240 U. S. 564, 57 I et seq., 36 Sup. Ct. 424, 427; Darnell v. Edwards (I9I7) 244 U. S. 564, 569 et seq., 37 Sup. Ct. 701, 703; Mississippi Ry. Comm. v. Mobile and Ohio Ry. (I9I7) 244 U. S. 388, 390, 39r, 396, 37 Sup. Ct. 602, 603, 605; People v. St. Louis, etc., Ry. (1898) I76 Ill. 512, 519 et seq., 529 et seq., 52 N. E. .292, 294, 297 et seq.

${ }^{14}$ Smyth v. Ames (I898) 169 U. S. 466, 526, I8 Sup, Ct. 418, 426; Missouri Pacific Ry. v. Kansas, supra note $\mathrm{I} 3$, at the pages cited.
} 
consent of the state. ${ }^{15} \mathrm{Mr}$. Justice Campbell, speaking for the Supreme Court of the United States, said: ${ }^{16}$

"Important franchises were conferred upon the corporation to enable it to provide the facilities to communication and intercourse, required for the public convenience. Corporate management and control over these were prescribed, and corporate responsibility for their insufficiency provided, as a remuneration to the community for their grant. The corporation cannot absolve itself from the performance of its obligations, without the consent of the legislature."

The relation of a private corporation to the state in such cases is so close and subordinate that a railroad company "cannot lease or alienate any franchise, or any property necessary to perform its obligations and duties to the state, without legislative authority."17 Allen, J., speaking for the Supreme Court of Kansas, said :18 "While the title to a completed railroad is'vested in the corporation, it is only private property in a qualified sense. Railroads, like all other public thoroughfares, are public instrumentalities."

Railroad companies, unlike strictly private corporations, owe a duty to the public under their charters and cannot therefore voluntarily cease to do business and dissolve without the consent of the state. In this, quasi-public corporations differ from strictly private corporations. ${ }^{19}$ The franchises of a railroad company and the corporate powers essential to the enjoyment of the franchises, are not subject to sale on execution unless the legislature authorizes or assents to the transfer. ${ }^{20}$ As the authority of the state is essential to the creation of a railroad corporation and the charter is a contract between the corporation and the state that the company will perform its functions, it cannot abandon its operations until released from performance, in some form, by the state.

While, as already observed, the state cannot compel a railroad corporation to continue operations that are unprofitable, if it surrenders its charter or its charter rights as to the line it proposes to abandon, the state may determine the conditions upon which such abandonment may take place. This discussion has reference only to the highway; it does not include equipment or movable property used in the operation of the railroad.

\section{(A) THE INTERESTS OF THE STATE}

The state has a direct interest in the maintenance of every highway. It is opened by the state, directly or through the agency of a corpora-

\footnotetext{
${ }^{15}$ Brooks-Scanlon Co. v. Ry. Comm., supra note Io; Erie Ry. v. Public Utilities Conm., supra note II.

${ }^{18}$ The York and Maryland Line Ry. v. Winans (1854, U. S.) I7 How. 30, 39, quoted approvingly in Thomas $v$. $R y$. (I879) Ior U. S. 7I, 83.

${ }^{17}$ Thomas $v$. Ry., supra note 16.

${ }^{18}$ State v. Dodge City, etc., Ry. (1894) 53 Kan. 377, 378, 36 Pac. 747, 748.

${ }^{10} \times$ Elliott, Railroads ( $3 \mathrm{~d}$ ed. Ig2r) sec. 700, and cases cited.

${ }^{20}$ Ibid. sec. 596.
} 
tion, for public purposes, to serve the needs of the state. The great highways for the movement of military forces, built by the Romans, exist to-day and the exercise of such power is common to every nation. The defense of a nation, in case of invasion, depends very largely upon the character of its highways upon which it may move its military forces, munitions and subsistence. Equally important to the state is the development of national wealth, the increase and maintenance of the values of taxable property. The increase in value of lands from a nominal acreage value to hundreds of dollars per acre, common all over this country, suggests the importance to the state of maintaining these values for taxation, and sources of revenue. Whatever depreciates the value of land and other property subject to taxation affects directly the revenues of the state. In a recent case where the abandonment of a railroad was under consideration, evidence was submitted tending to show that such abandonment would result in depreciating the value of lands, in a large part of the county, fifty per cent., or "a million dollars loss" in the value of farm lands. Other estimates placed the loss upon the farm lands in that portion of the county at from "Io per cent. to 40 per cent. of the present value," according to the distance to other railroads. The loss to the state in such a case is not and cannot be questioned. The more extensive the railroad which is to be abandoned, the greater the territory dependent upon it for a rail highway, the larger the loss of revenues to the state.

\section{(B) THE PRIVATE INTERESTS}

The loss in property values by the people who will be deprived of a railroad facility is too apparent for discussion. The state is morally bound to protect its people who have gone out upon these highways, practically at the invitation of the state, and invested in lands and industrial enterprises, the values of which are dependent upon the continued operation of the rail highway. We do not say that the state is to be held responsible for these losses; but it is its political duty to protect its people, in so far as it can do so, by the maintenance of rights to use highways which have been established by governmental authority. The people who suffer losses by reason of the abandonment of a railroad have no right of action against the company or the state for financial indemnity for such losses. But nevertheless the state has a duty to perform. The duties of the state are illustrated by many laws and statutes dealing with different phases of the subject. For example, a city street, generally speaking, may not be closed without the consent of or compensation to the abutting owners. ${ }^{21}$ A country highway may not be closed without such consent.22 Even a private easement over lands for passage to and from a property may not be closed against the

\footnotetext{
${ }^{21} 27$ A. \& E. Enc. Law (2d ed. I904) Ir3, Ir4; 2 Elliott, Roads and Streets (3d ed. I9II) sec. II 80 .

$=$ Ibid. secs. 882,883 .
} 
consent of the holder of the easement. There are public regulations relating to maritime adventures, the employment of seamen, intended to prevent the stranding of a ship or its passengers in foreign ports. Equality of public service to all shippers and localities is required by statutes. These and other instances that might be cited show the care of the state in protecting its citizens against any action that will unduly curtail their free movement or prejudice their privileges, or render their properties less valuable or accessible.

Courts, says Elliott, "have also recognized an additional right in the adjoining owner, distinct from his rights as a member of the general public, namely, the right of access to his premises, or as it is called in New York, the 'easement of access.' This is so far regarded as private property that not even the legislature can take it away and deprive the owner of it without compensation."23

In reference to the forfeiture or expiration of charters for turnpikes or toll roads the same author states the law as follows and cites authorities in support thereof : ${ }^{24}$

"If the corporation owning the turnpike suffers it to get out of repair, the corporate franchise may be forfeited to the state, and in that event the road will become a public way of the governmental corporation or body having control of roads of like character. This result will follow if the road is abandoned by the private corporation. ... A corporation accepting a charter authorizing the construction of a public highway ought to be held to take the franchise granted, upon the condition that on the dissolution of the corporation the road shall remain open to the public. The right to take tolls for a specified period should be deemed to be all the benefit that the corporation was authorized to receive, and, having received this, there should be no right to close the road against the public travel. ${ }^{25} \ldots$. In one of the oldest cases upon this subject it was declared that highways could be discontinued only by authority of law and never by the act of individuals." footnote the author says: 27

"The fact that a private corporation desires to abandon the road and does abandon it, leaves it a passage way for travel as long as the public chooses to treat it as such. The act of the private corporation does not take away the rights of the public. [Citing authorities which support the text] ...."The author also states $:^{28}$ "A toll bridge erected under a legislative grant for the use of the public for ordinary travel is in so far a highway that upon its abandonment by the owners the public may claim the right to maintain and use it if the local authorities so elect. A highway once legally established cannot lose its character, if the public duly object, except by its extinguishment or vacation in due course of law. [Many state cases are cited.]"

s Ibid. sec. 882 and cases there cited.

${ }^{24}$ I Ibid. sec. 80 .

${ }^{25}$ Pittsburgh, etc., Ry. v. Commonwealth (I883) I04 Pa. 583.

${ }^{20}$ Dawes v. Hawkins (I860) 8 C. B. (N. S.) 848.

${ }^{\prime \prime}$ I Elliott, Roads \& Streets (3d ed. rgII) sec. 8o, note I2.

${ }^{23}$ Ibid. sec. 49. 
The private parties affected by the abandonment of a rail highway may be so extended from the line and so indefinite as to boundary as to make it impossible to determine the territorial limits within which a consent of parties so affected should be obtained.

It must, therefore, be left to the state to determine and fix the conditions of abandonment so that the public and private interests affected shall, to the extent permitted by constitutional law, be protected.

\section{IV}

Coming now to our second question: Upon what terms and conditions should the state consent to an abandonment of an existing railroad? We refer only to the highway. The equipment, which is personal property used in operating the highway, belongs to the company and, when the company ceases operation, may be removed and disposed of for the benefit of its stockholders. The operation of the railroad is important, but here we are met with the rule that private parties 'cannot be compelled to operate at a loss.' The equipment belongs to operation and is not an integral part of the highway.

The contention by the railroad companies up to the present time has been that they could take away everything-rails, ties, bridges, buildings, etc., and sell the same at scrap value, thus realizing as much as possible to reduce their losses. If no other interests were involved this would undoubtedly be true. But, as already noted, there are other interests quite as important and entitled to protection as that of the railroad investor. All the risks assumed by the railroad company were in consideration of the right to enjoy the profits that should arise out of the investment. It obtained its right of way, paying the full price of the land, knowing that if it abandoned the operation of the railroad the right of way would revert to the owners of the fee and be a total loss to the investor. ${ }^{29}$ The state grants these rights or allows them to be acquired by right of eminent domain to create a permanent public highway of this type to develop its territory and increase its national wealth. The investors in private business along the line of the railroad did not assume any risks as to the railroad. They do not share in the profit if the railroad is a successful investment. They were invited to go out along this highway and invest their money in private enterprises and develop the resources of the country. To scrap the highway will leave these people without access to the markets. The state is just as much bound to protect the private interests that have been built up along the line of a railroad, in so far as it can equitably do so, as it is to protect the property rights of investors in the railroad. And in determining the superior rights the maxim salus populi suprema lex should prevail.

In the case of canals and toll roads we find that when the franchise

\footnotetext{
${ }^{2}$ New Mexico v. United States Trust Co. (1898) I72 U. S. I7r, 19 Sup. Ct. I28; Northern Pacific Ry. v. Toumsend (I903) I90 U. S. 267, 27I, 24 Sup. Ct. 671, 672; Rio Grande Ry. v. Stringham (Igr5) 239 U. S. 44, 47, 36 Sup. Ct. 5, 6.
} 
expired, or when the operating company desired to abandon further operation, it could remove its personal property but could not destroy the canal or toll road. They were highways of peculiar type and were constructed by private capital, in many instances, under the public policy referred to, in order to develop the territory and strengthen the power of the government by inducing people to go out along the line of a better highway and locate for business purposes. The canal, therefore, was to remain; the toll road was to remain, both complete as a highway, to be thereafter operated, if operated at all, under further provisions to be made by the government. The government might operate them or it might provide that the people along the lines whose property interests were affected might organize and operate them without paying for the highway. The investors in the railroad should have no lien, for scrap value or otherwise, on the public highway. It may be, and in many cases it is the fact, that the government and private parties along the line could not afford to pay even the scrap value for the highway and then furnish the money and capital necessary to buy equipment and operate it to the small extent necessary to save the situation. But if the highway belongs to the public and the public has the right to say that it shall remain a highway of the type constructed, then it may be quite feasible in many cases to protect the public and the private interests by providing sufficient funds to secure equipment and capital to operate the line.

It undoubtedly is true in some cases, where railroads have been built for special purposes, that the entire abandonment of the highway may be permissible. Where a railroad was built to take the single traffic of a mine and the mine is exhausted and no other traffic has been created to justify the maintenance of the highway; where a road was built to carry out forest products, lumber, etc., and the forest may be exhausted and the lands are not usable for purposes that will create traffic; in such exceptional cases the state may find no necessity for maintaining the highway and would allow the investor in the highway to scrap it. No private or public interest would be affected in such cases. But such is not the case where the highway serves existing public and private interests. In these cases the public and private interests should be protected even to the extent of increasing the loss to the investor in the railroad. In such cases the question of who assumed the risk is vital. The builders of a railroad secure valuable franchises and opportunities for profitable investment. In consideration of these grants they assume the risk of creating a highway the entire abandonment of which will work financial injury to public and private interests. In such cases the loss-for there must be a loss-should fall upon the group that assumed the risk for the prospective profits in operation and created the conditions under which loss must be incurred.

Congress provided : $:^{30}$

${ }^{30}$ Act of Feb. 28, 1920 (4I Stat. at L. 456, 477). 
"After ninety days after this paragraph takes effect no carrier by railroad subject to this Act shall . . . abandon all or any portion of a line of railroad, or the operation thereof, unless and until there shall first have been obtained from the Commission a certificate that the present or future public convenience and necessity permit of such abandonment.

"The application for and issuance of such certificate shall be under such rules and regulations as to hearings and other matters as the Commission may from time to time prescribe, and the provisions of this Act shall apply to all such proceedings."

The Supreme Court of the United States, passing upon the right of a railroad company owning and operating thirty miles of railroad wholly within a state of the Union to abandon its line, speaking through Mr. Justice Van Devanter, said : ${ }^{31}$

"These considerations persuade us that the paragraphs in question should be interpreted and read as not clothing the Commission with any authority over the discontinuance of the purely intrastate business of a road whose situation and ownership, as here, are such that interstate and foreign commerce will not be burdened or affected by a continuance of that business."

This recognizes the power of the state to determine whether there may be an abandonment of the operation of a railroad-the Federal Government to determine it as regards interstate commerce, and the state of the Union in which the road operates to determine the question as to intrastate commerce. In this case the Interstate Commerce Commission required the company to hold the road for a certain time and give the parties in interest an opportunity to raise money and purchase the highway at a price presumed to be its scrap value. This procedure if adopted generally throws the entire burden of loss upon the state or upon innocent parties who are not usually able to finance the enterprise and thus protect themselves against great property loss. The organization of farmers and men of small business along the line to purchase and finance a railroad that has proved a failure is impracticable in most cases.

In consideration of the conditions stated and the general law upon this subject, it seems more consonant with equity and justice that the loss of the highway should fall upon those who were to profit by it if it proved a profitable investment. The state and those who are made to suffer by the abandonment should not be compelled to pay for the highway, even at its scrap value. Where there is a demand for the maintenance and operation of the highway to protect the state and private owners from irreparable loss, we submit that the state should require that it remain a complete highway, of the type dedicated to public use, its operation only to be provided for by the state or by the persons whose property interests would be seriously affected by its abandonment.

"Texas v. Eastern Texas Ry. (rgzz) 42 Sup. Ct. $28 \mathrm{r}, 284$. 